\title{
Women Wage-Earners in Bone Regency Indonesia
}

\author{
Yumriani \\ Heri Tahir \\ Rabihatun Idris \\ Department of Sociology, Universitas Negeri Makassar, Makassar, Indonesia \\ JIn. Bonto Langkasa Kampus Gunung Sari Baru, Postal Code 90222 \\ Email: yumriani69@gmail.com, profheritahir@yahoo.com, rabihatun_idris@yahoo.com
}

Doi:10.5901/mjss.2016.v7n4p

\begin{abstract}
This research aims at describing why the fisherman's wife works as a fishmonger. This research is a qualitative approach. This approach provides an explanation of the facts based on the target or object that has been observed to describe women wageearners in the Sub-district of East Taneteriantang, Bone Regency Indonesia. The research model is not preceded by the design of a particular theory. However, this research is directly into the field. The data were the source of a theory and in the end the theory appears based on the data obtained in the field then it creates a new theory. The results of the studies showed that women as the fisherman's wife who works as fishmonger are dominated by the fulfilment of the economic needs. It means that they work to help the husband to add the family income
\end{abstract}

Keywords: women, fisherman's wife, Bone Regency

\section{Introduction}

There is a change of the social status of women as fishing communities who have been lived more than ten years. This change is from fishmonger to fish supplier. It means that they serve the fishmonger from several other areas in South Sulawesi. They are interested in this job because it is not difficult for them. They can perform activities being a fishmonger and fish supplier in their home. Retailers and consumers visit their home to buy fish. They can choose the fish directly based on their needs.

In a fisherman family, if husband goes to sea for a long time, all things that are existing on the land should be handled by his wife such as providing the children's needs for school, educating children at home, buying furniture and kitchenware, taking credit, paying the credit, buying equipment to the sea (pandu 2006, p.92).

According to More (cited in Latif, 2010) Dual role of women is a crucial phenomenon to be examined. Women can be analysed in relation to population in the community for example whether their functions within an institution are in balance with the other institutions. The formulation of the problem in this research is why the fisherman's wife worked as a Fishmonger in the Sub-district of East Taneteriantang, Bone Regency.

This research aims at analysing women wage-earners in the Sub-district of East Taneteriantang. This research also describes why the fisherman wife works as fishmonger in the Sub-district of East Taneteriantang, Bone Regency. In general, this research is expected to provide an advantage for the development of the science of sociology. In particular, it can give us knowledge about the socioeconomic life of fishing communities in the Sub-district of East Taneteriantang, Bone Regency.

\section{Review of Related Literature}

\subsection{The Social Interaction Theory of Women Wage-Earners}

According to Kusnadi, et al (2006), the fisherman's wife is one of the important social which is very potential in the development of coastal regions. It is because some considerations. First, in the system of work division, the fisherman's wife plays a large role in socioeconomic activities on the land. Meanwhile, her husband plays a role in the sea to make a living by catching fish. It means that land is the domain of women, while the sea is the domain of men. Second, the 
impact of the above work division system requires that the coastal woman should always engage in public activities, namely making a living for the family as the anticipation if her husband does not have income. The activities to go out to sea is speculative activities and tied by season. Third, the work division of coastal communities and the lack of certainty of revenue per day in the household has put women as one of the pillars of household necessities of life.

According to Narwoko (2004, p. 232), with its economic function then the relationship among family members is not only based on the importance to continue the descent but also the system of working relationships. It means that husband not only plays a role as the head of the household but also as the head in the works. Therefore, the relationship between husband and wife can be seen as the colleague that is influenced by interests in cooperation. This function is rarely seen in a family in the city and even this function can be said to be completely reduced or lost.

There are four different typologies of social action reviewed by Weber. The first is instrumental action or zweckrational. It is the action that is conducted by considering the objectives and the tools used to achieve the goal. In addition, it is an action that reflect effectiveness and efficiency. The second is value based rationality or wetrationalitat. It is the action which regards the tools as a conscious consideration and calculations because purposes related to the values have been already determined. The third is traditional action. It is the action that is performed based on habit without planning and without conscious reflection. The fourth is effective action. It is an action which is conducted and dominated by feelings or emotions without intellectual reflection or conscious planning (I.B. Wirawan: 2013, p. 99).

According to Balasong and Hasmawati (cited in Latief 2010, p. 43), in taking care of the household, a mother will embody the model of self-control. The goodness and beauty of a wife are not only based on physical appearance, but also the ability to be a true woman who is able to take the required decisions.

Engels (Fakih, cited in Narwoko, 2002) explains that the gender differences between men and women are going through a very long process, namely the process of socialization, reinforcement, social construction, cultural construction, religious construction and even through state power. Because of this long process, then gradually gender between male and female is like the provisions of God that cannot be changed. In addition, the socialization of social construction of gender in the evolution in the end affects the men to be strong and aggressive. Therefore, this kind of social construction makes men to be trained and motivated to maintain the characteristic, and finally they become stronger and bigger. However, with the aim that every characteristic is usually attached to a particular gender as long as this characteristic can be exchanged, then the gender is the result of the community construction, and it is not the god's will (Fakih, 1997, p. 10). Thus, the gender as a concept is the result of thinking or human engineering. It is formed by the community so that gender is dynamic. It can be different because of different customs, cultures, and religions, systems of values, community, and certain ethnic groups. In addition, gender can be changed because of history, political change, economic change, social change, cultural change, and the progress of development. Therefore, gender is not universal but it is generally circumstantial people. It is therefore not the case of chaos or misrepresentation of the meaning of what is sex and gender.

\subsection{The Social Action Theory}

Blood and Wolf (cited in mustadjar 2011, p. 21) reveals that there are some actions in relation to resources in the family decision-making process from a gender perspective namely (1) the dominance of wife, (2) the dominance of husband, (3) balanced, and (4) autonomy (husband and wife choose control automatically and separately) on the decision-making for specific areas. In order to be able to keep the existence of the family, the buginese family develop a balance social interaction through the perception of patriarkhi. In this perception, bugis women always put the existence of appreciation. They maintain the authority of the husband. They put work division based on ability, potential and fairness. They keep the internal relationships through disclosure of compassion. Therefore, the existence of the family can play many roles in carrying out its duties and obligations as part of a family and social environment (Mustadjar 2011, p. 126).

According to Mustardjar (2011, p. 316) dual role displayed by the wife is to motivate herself to be responsible in taking care of the children as well as and educating them. Motivation in the dual role of women as wives always needs a family environment. The environment is intended to maintain a good communication and relationship with her husband and children.

\subsection{The definition of Gender}

Gender is a concept referring to the role and responsibilities of women and men. It is influenced by social culture in the community, which can be changed and exchanged. The fundamental distinction between gender and sex is biologicalanatomical characteristics (in particular reproductive and hormonal system), followed by the body's physiological 
characteristics, which determine whether a person is man or woman. For example: woman is able to experience menstrual, pregnant, giving birth and breastfeeding. Meanwhile, man can produce sperm. On the contrary, gender refers to the differences in social roles and responsibilities for women and men which are formed by culture. It means that culture forms the social characteristics of women and men. The differences in the roles and responsibilities are related to the ability of a biological sex. For example: women are more dominant for household chores, secretary, kindergarten teachers, midwives and nurses. They are regarded as more patient. In addition, there is an assumption that women are more appropriate for those jobs (Christian, 2013).

Talcott Parsons's AGIL schema presents the four functional requisites or imperatives of any system of action. They consist of adaptation (A), goal attainment $(\mathrm{G})$, integration $(\mathrm{I})$, and latent pattern maintenance $(\mathrm{L})$. It is a concept of an activity that is directed towards the fulfilment of the needs of the system. The system must implement these functional requisites, thus it can be everlasting. Adaptation is a system that has to deal with the urgency of external situation. This system must adapt to its environment and adapt to the environment with its needs. The goal attainment is a system that must define and achieve the main goal. Integration is a system which must arrange relations among its components. It must also manage the relationship among the three other functional requirements $(A, G, L)$. Latent pattern maintenance is a system which should provide, maintain and renew the motivation of individual and cultural patterns that create and sustain the motivation. Parson has a clear idea about the levels of social analysis based on their interrelations. In the system of parson, these levels have been set up in two ways. First, each lower level provide conditions and energy that are required by high level. Second, the high level controls the lower level (George Ritzer, 2012, p. 407).

\subsection{The dynamics of socioeconomic life of women wage-earner}

The purpose of sociology is to realize a harmonious social life with a wide range of institution related to the individual, the family and the social environment (Mustadjar, 2011, p. 85)

According to Yuliati, $(2003$, p. 260) gender is a role segregation between women and men in social life and is part of the culture. It concerns the idea of treatment and even the technology of gender bias or sexism is closely related to cultural contribution. In addition, gender is the differences category between men and women in terms of language, behaviours, thoughts, food, space-time, taboo, technology, media, fashion, education, profession, tools of production and household items. Men and women have a clear difference with these things. Therefore, gender is purely the result of a cultural process. Empowerment of men and women is a necessity. With their organs and various characteristics, the fundamental obligation will be formed naturally. This requirement may not be exchanged so that their empowerment has been clear. Another distinction is the obligation created from a social process about men and women as well as their consequences. Gender as an object of study is basically discussing the various consequences of the distinction between men and women. In fact, the differences between men and women create the obligations that are not always providing justice for both of them. It is unfortunate if the actors do not recognize their obligations, and even they enjoy them as a noble job. The distinction between men and women has long been conducted, and it is an interesting study. There are many theories put forward to give description why the distinction is performed. The theories consist of nature theory, culture theory, structural functionalism theory and theory of men and women with their consequences.

Husband usually plays a role in deciding everything. However, behind him there is a wife who gives the best consideration for the decision. In the biography of the world war, there will be found that the major decision is taken because they have a very supportive wife. On the contrary, behind the big bad men, there is a very destructive wife. The position of a wife will be very influential for her husband. A wife always give input and execute ideas. In addition, she never prevents what her husband duty is (Akatiga, cited in Latief, 1990).

\section{Method}

This research is a qualitative approach. This approach provides an explanation of the facts based on the target or object that is observed with the aim at describing women wage-earners in the Sub-district of East Taneteriantang, Bone Regency Indonesia. The research model is not preceded by the design of a particular theory. However, this research is directly into the field. The data were the source of a theory and in the end the theory appears based on the data obtained in the field then it creates a new theory. This research is a qualitative approach. This approach provides an explanation of the facts based on the target or object that is observed with the aim of describing women wage-earners in the Subdistrict of East Taneteriantang, Bone Regency Indonesia. The research model is not preceded by the design of a particular theory. However, this research is directly into the field. The data were the source of a theory and in the end the theory appears based on the data obtained in the field then it creates a new theory. The target of this research is the 
individuals and groups who work as wage-earners and undergo changes in socioeconomic life. The primary data and secondary data were obtained directly from the target of this research. The data were collected through in-depth interviews to explore the facts that constitute a social phenomenon in this research.

According to Bagdon and Biklen (cited in Usman 2009, p. 84), data analysis is the process of search and the preparation of systematic data. It is used through a transcript of the interview, notes field, and documentation. They can increase understanding towards research finding. Fundamental thing in the qualitative research is the researchers as the main instrument. Therefore, the data analysis is undertaken ranging from research process, data collection, and report. The data analysis of qualitative research is conducted with sequence analysis activities gradually. The first is data reduction. This process focuses on the selection, simplification, abstraction and transformation of data obtained from field notes. The second is data presentation. It is a compilation of information in a conclusion statement that allows to attach findings based on the reduction and the presentation of the data.

In addition, researchers also conduct in-depth interviews, observation and documentation. It aims at determining why the fisherman's wife worked as a fishmonger and wage-earner. In qualitative research, the collected data are generally in the form of words, pictures. They are not figures, and its nature is only as supporting data. The data can be in front of transcript of the interview, the fields of records, photos, documents, notes and situation (Danim, 2002, p. 61). Description or written narrative is essential in a qualitative approach, either in the data recording or dissemination of research results.

\section{Results and Discussion}

The results of the studies showed that women as wives of fishermen who worked as a fishmonger are dominated by the fulfilment of the economic needs. It means that they work to help the husband to add the family income. Likewise, the other women work as fishmonger because this work is conducted by the parents from generation to generation. Therefore, they do this job not only for economic needs but also because the customs in the fisherman family. They are obliged to involve themselves as workers and fishmonger.

The places to sell fish are varied. If there are some supplies, they sold fish to the city, and even they also supply fish to other areas. However, if there is little supply, they only sell the fish at the market. They also usually sell the fish by calling their customers to pick up the fish in their house to be sold to a residential area. The customer usually called "pagandeng". These customers sell to the houses of the community.

Some of them also work due to coercion to meet the economic needs of the household because they have many family members. The other reason is the social life that is different from other fishermen. Their job as the fishmonger and her husband as fisherman are not inherited from their parents. They do these jobs because they join and live in this area. Therefore, this work is the main livelihood. It means that this work should he carried out in order to meet their economic needs.

According to Rauf (2002, p. 114) ideally every household member has each task. Thus, a good cooperation can be established. Who does and what should done is the patterns of work division in the household, thus the work should not be done only by the wife or certain members. The work division in the household can also be differentiated based on physical form and type of work. Therefore, "who" means the members of the family whether it is man or woman. Decision-making in the household in three cities where research were conducted turns out to be equivalent. It means that husband and wife agree on each task in the household. They also agreed on other tasks that must be performed by members of the household. In Ujung Pandang, the work division in the household is based on the results of the deliberations. Likewise, husband and wife conduct their tasks based on an agreement.

There are several other factors why the fisherman's wife is involved in activities as fishmonger. It is caused by the fulfilment of the economic needs of the family. In addition, it is also due to the high number of children in the family. Therefore, the level of their needs are becoming increasingly high. With this condition, the fisherman's wife must be involved to do this work. It means that the wife does this job because there is a compulsion element. Furthermore, the involvement of fisherman's wife as a fishmonger is also caused by the desire to increase earnings, and to change the socioeconomic life.

Holistically, the researchers can describe the activities of fisherman's wife based on work structure. She has dual roles in the household. She plays a role as a domestic worker. However, she has to serve her husband to prepare her husband needs. In addition, he also has a responsibility to help her husband in order to fulfil economic needs. Another point that needs to be reported is that the fisherman's wife become fishmonger because it is dominated by the desire and willingness as a wife to assist her husband in terms of fulfilling economic needs. 


\section{Conclusion}

The fisherman's wife become fishmonger because it is dominated by the desire and willingness as a wife to assist her husband in terms of fulfilling economic needs. The socioeconomic life of fishermen families is truly simple and unique. It turns out that their success in carrying out its activities as the fishmonger cannot be seen from the level of education that they achieve. It can be seen from the socioeconomic background of their families from generation to generation. Therefore, the activity as the fishmonger is a cultural heritage that should be performed. In social life, the profession as a fishmonger is a benchmark of the success of her husband. In addition, it also becomes the social status in the fishing community.

Other factors that cause wives of fishermen engaged in the activity as a fish seller. It can also occur due to the factor of family economic needs and the large number of children in a family of fishermen, so the higher the level of their needs. Under these conditions, the fisherman's wife to work because of the urgent need, in other words, because of compulsion.

\section{References}

A Moore C. Ollenbugr, Jene. (2002). Sociology of Women (Sosiologi wanita). (2nd Ed). Jakarta: PT Rineka Cipta.

Danim, Sudarwan. (2002). A Qualitative Study (Menjadi penelitian kualitatif). Bandung: CV Pustaka Setia.

Fakih, Mansour. (1999). Analysis of Gender and Social Transformation (Analisis Gender dan Tranformasi Sosial). Yogyakarta: Pustaka Pelajar.

Kritina ni Nyman. (2013). Reference: Pengarasutamaan Training Modules Gender Health (PUG-BK) For Health Workers, Ministry of Health of Republic of Indonesia (Referensi: Modul Pelatihan Pengarasutamaan Gender Bidang Kesehatan (PUG-BK) Bagi Tenaga Kesehatan, Kemenkes RI). Jakarta: Badan Pengembangan dan Pemberdayaan SDM Kesehatan Balai Besar Pelatihan Kesehatan.

Kusnadi, et al. (2006). Coastal Women (Perempuan Pesisir). Yogyakarta: LKiS.

Kusnadi. (2009). the Existence of the Coastal Fishermen and Economic Dynamics (Keberadaan Nelayan dan Dinamika Ekonomi Pesisir). Yogyakarta: Ar-Ruzz Media.

Latief .M. Ali. (2010). Dual Role of Women. (Studies in 5 Women Working as a civil servant) in Makassar (Peran Ganda Perempuan. (Studi pada 5 Perempuan Bekerja sebagai Pegawai Negeri Sipil) di Kota Makassar). Dissertation. Makassar: UNM.

Mustdjar, Musdalia. (2011). Gender in the Buginess Family of Makassar (Gender dalam Keluarga Bugis di Kota Makassar). Makassar: Pustaka Unhas Makassar.

Narwoko. (2004). Introduction to Sociology Text And Applied (Sosiologi Teks Pengantar Dan Terapan). (1st Ed). Jakarta: Kencana.

Pandu. M.E, et al.. (2001). Women of Sulawesi Selatan (Perempuan di Sulawesi Selatan (iktisar regional). (Dissertation). Makassar: Pustaka Unhas Makassar.

Rauf Rabihatun. (2008). Female Labor Force, Case three Cities in South Sulawesi National Library (Angkatan Kerja Wanita, Kasus tiga Kota Di Sulawesi Selatan itan Perpustakaan Nasional). Makassar: Katalog dalam terbitan (KDI).

Ritzer, George. (2012). Theory of Sociology From Classical Sociological to Postmodern Developments Recent (Teori Sosiologi Dari Sosiologi Klasik Sampai Perkembangan Terakhir Postmodern). (8th Ed). Yogyakarta: Pustaka Pelajar.

Tupamahu, Maria K. (2012). Analysis of Economic Behavior of Women's Group Pappalele in Ambon (Analisis Perilaku Ekonomi Kelompok Perempuan Pappalele di Ambon). Unpublished Dissertation. Makassar: Universitas Hasanuddin.

Usman Husaini. (2009). Social Research Methodology (Metodologi Penelitian Sosial). Jakarta: Ikrar Mandiri Abadi.

Wirawan, IB. (2012). Social theories in paradigm, social facts, social definitions, and social Behaviour (Teori-teori sosial dalam paradigm, fakta sosial,Definisi Sosial,dan Prilaku social). (1st Ed). Yogyakarta: PT Kharisma Putra Utama, Kencana Pranamedia.

Yayuk Yuliati. (2003). Sociology of Rural Life (Sosiologi Pedesaan). Yogyakarta: Pondok Pustaka Jogyakarta. 